\title{
THE IMPACT OF ECOLOGICAL FACTORS ON TOURISM DEVELOPMENT IN KVEMO KARTLI REGION
}

\author{
NINO LETANDZE \\ Assistant Professor \\ Georgian National University, Georgia \\ nletandze@mail.ru
}

https://doi.org/10.35945/gb.2018.06.037

\section{KEY WORDS: ECOLOGICAL SAFETY, ECOLOGICAL SAFETY OF TOURISM, TOURISM POTENTIAL,} RATIONAL NATUREUTILIZATION, ENVIRONMENT

Human beings are part of nature with all their uniqueness. By their unreasonable action people very often violate the environmental integrity and sustainability. These two factors are harmful and threaten valuable living of a human being.

It is difficult to evaluate the role of ecological threats, which are of particular importance in modern conditions due to a number of reasons: 1) The basis of the frequent ecological occurrences is not only natural, but also anthropogenic causes; 2) Ecological disasters have become more frequent during these some last decades; 3) The relationship between the population and the environment has been expanded and has become intensive, which has led to increased environmental vulnerability; 4) Spatial scale of geo-ecological phenomenon (local and from regional to global) has changed; 5) Health of the population has become the indicator of ecological welfare.

The activation of these processes has put forward ecological safety problems, including tourism, as the ecological factor determines the number of tourists for host destinations.

The safe and sustainable development of modern tourism is derived from the interaction of economic, ecological and social systems. Environmental safety of tourism and ecological tourism are often used in one context that prevents the generalization of these events and formation of their essence. Ecological tourism is a form of organizing a journey in a natural and cultural environment that will reduce the negative impact of tourists on the environment and landscape. Ecological security can be described as protecting the vital interests of the community from internal and external adverse effects which threaten solid functioning of the ecological system. Ecological security of tourism can be considered as functioning of the "tourism-natural environment" system without the threat of activation of destructive processes

The essential condition for tourism development, as of an integral part of economic relations is the ecological condition of the region as it affects human health and is one of the social indicators of social development. In general, ecological level is a determining factor for the social and economic, ecological, demographic and sanitary-hygienic conditions of the country.

Georgia is ranked $70^{\text {th }}$ in the report of WHO (World Health Organization) 2018 on mortality caused by air pollution. During the past five years, the frequency of tumors, respiratory diseases and allergies has significantly increased in the country, which possibly is mostly caused from deterioration of ecological conditions. According to the National Center for Disease Control and Public Health, the overall tendency of respiratory disease in adults has increased by $20 \%$ in adults and by $27 \%$ in children. One of the ecological threats may also be the import of dangerous food products that puts food safety under a question.

Kvemo Kartli region (after Imereti) is one of the major pol-

Percentage of morbidity of family members in Kvemo Kartli region (data of $\mathbf{2 0 0}$ respondents):

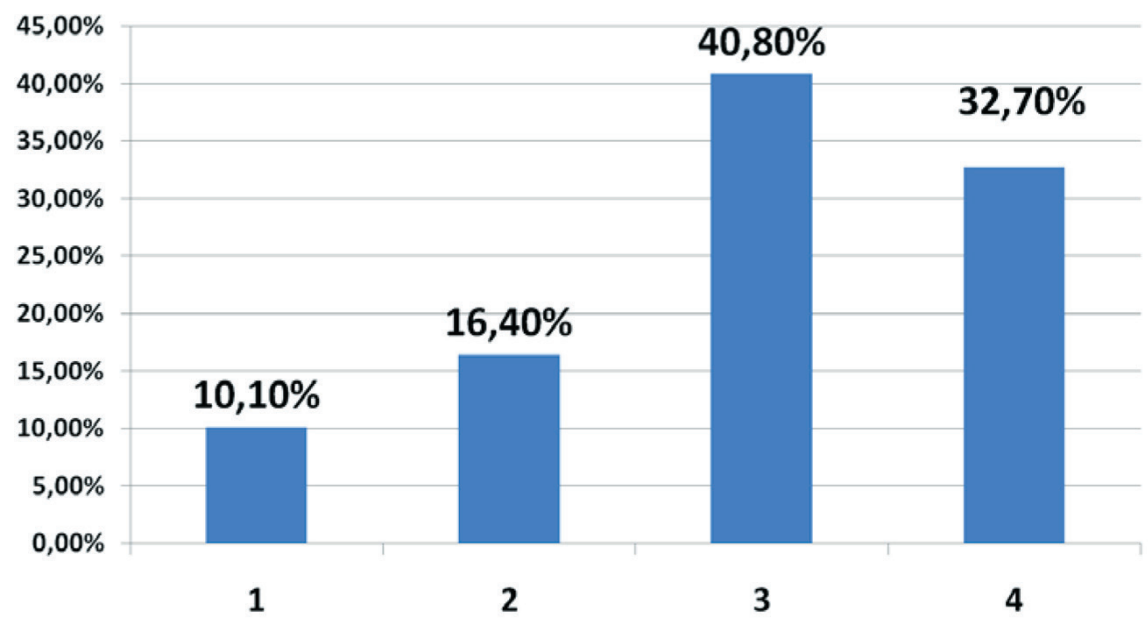


lutants of atmospheric air in Georgia. Its share was of $28,12 \%$ in 2015 in emission of harmful substances from enterprises. This figure is less than share of Imereti (46,12\%). In Kvemo Kar$\mathrm{tli}, 71,26 \%$ of the emissions fall on the industry sector, $28,74 \%$ - on energy sectors.

In order to identify the environmental problems of human health we conducted a survey in Kvemo Kartli households.

The results of the survey showed that $10.1 \%$ of respondents had one member of the family sick, in the families of $16.4 \%$ respondents they have two sick people. More than $70 \%$ of respondents have three or more members with chronic diseases. In fact, in Kvemo Kartli households they have average one healthy member. Residents of Tetritskaro region often complain of health problems, where approximately $43 \%$ of households have a member with chronic disease who need long-term treatment within 12 months.

It is important to note that the industries that influence the environment can not provide economic growth in Kvemo Kartli region.
Self-assessment of economic situation by families of Kvemo Kartli region (3000 respondents):

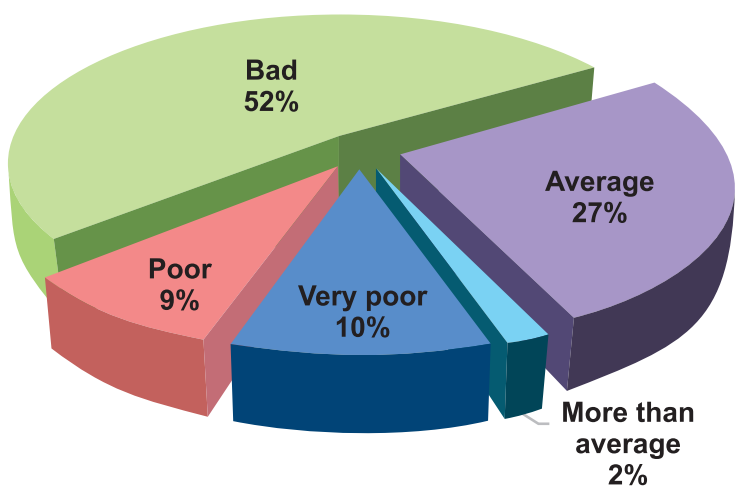

According to the criterion of material deprivation, 34.5\% of Kvemo Kartli families are poor (by deprivation poverty, family is poor if it can not perform certain activities and lacks the items that are typical for the active living in society). Poverty in the city $(23.9 \%)$ is much less than in the village $(41.3 \%)$.

Distribution of the population of 15 years and older according to economic activity in Kvemo Kartli region in 2017 (one thousand people):

\begin{tabular}{|l|c|c|c|c|c|c|}
\hline & 2012 & 2013 & 2014 & 2015 & 2016 & 2017 \\
\hline Total of 15+ population & 334,0 & 332,5 & 334,1 & 333,6 & 333,4 & 326,8 \\
\hline Total active population (working force) & 211,8 & 211,2 & 225,8 & 238,7 & 228,7 & 236,3 \\
\hline Employed & 185,4 & 192,3 & 200,5 & 210,5 & 204,6 & 203,1 \\
\hline Hired & 74,0 & 72,4 & 76,7 & 81,3 & 74,1 & 84,5 \\
\hline Self-employed & 111,0 & 119,7 & 123,8 & 129,1 & 130,3 & 118,6 \\
\hline Unknown & 0,4 & 0,2 & 0,0 & 0,1 & 0,1 & 0,0 \\
\hline Not employed & 26,4 & 18,9 & 25,2 & 28,2 & 24,2 & 33,2 \\
\hline Population outside workforce & 122,3 & 121,3 & 108,3 & 94,9 & 104,6 & 90,4 \\
\hline Unemployment rate (in percentages) & 12,5 & 9,0 & 11,2 & 11,8 & 10,6 & 14,1 \\
\hline Activity rate (in percentages) & 63,4 & 63,5 & 67,6 & 71,5 & 68,6 & 72,3 \\
\hline Employment rate (in percentages) & 55,5 & 57,8 & 60,0 & 63,1 & 61,4 & 62,2 \\
\hline
\end{tabular}

\section{Source: National Statistics Office of Georgia http://geostat.ge/regions/}

According to the Department of Statistics of Georgia, the population of Kvemo Kartli region was 429.7 thousand in 2017 and among them 203,1 thousand, i.e. 62.2\% are employed. According to this data, the unemployment rate in the region in 2017 was $14.1 \%$ and in $2015-11,8 \%$. We have investigated the results of the survey conducted by the Institute for Social Research and Analysis in 2015, according to which the unemployment level in Kvemo Kartli constituted 26.1\%. These figures may be higher if we consider that more than $30 \%$ of the region's population is employed in households and their source of income is agricultural products. Based on the same source, we found a self-assessment rate of the economic situation of the population of the region, according to which half of the population lives in poverty.
Our attention was paid to Kvemo Kartli as a very attractive touristic region. It has a great potential for tourism development thanks to its cultural and historic heritage: there are more than 650 historical monuments in the region, some of which, about 300 monuments are included in tourist destinations. The world's attention has been drawn and the discovery of primitive human remains in the Dmanisi site of former city is considered as a special archaeological discovery. It is noteworthy that Gardabani Managed Reserve (3484 ha) and Algeti National Park (6822 ha) occupy 1,57\% of the territory of the region, having recreational and resort and soil protection importance. Eco-tourism trends, such as pedestrian, horse-riding and cultural tours, are currently being developed in the protected area. The National Park has quite high potential for 
ecotourism (hiking, horse riding, photo and video recording, bird watching, ecological and botanical tours). The named tourist resources are quite good enough for Kvemo Kartli to become an active tourist region for both international and domestic tourist visits.

The total number of visits by domestic visitors in Georgia in 2017 reached 12.64 million, that is $2.5 \%$ less than for the same period of last year.

According to data of 2017 of the National Statistics Office of Georgia, 55,000 visitors have visited Kvemo Kartli region. During the same period in 2016, 61,000 visitors visited the region. We note that the number of tourists and visitors in the region is decreased. The Kvemo Kartli Regional Administration could not find statistical data about the exact number of tourists in the destinations. Considering the approximate number of visitors of protected areas, national parks and museums, we can conclude that the capacity of destinations in Kvemo Kartli is far more than their current load.

It is well known that employment and poverty reduction are the most valuable outcomes of tourism. Taking into account these factors, we can say that Kvemo Kartli region has a significant tourist potential to meet the government's economic challenges: to increase revenues and create jobs. It is possible to involve residents of nearby territory of Algeti National Park in eco-tourism activities and in various social projects such as training local population to provide guide ser- vices, development of guesthouses and catering facilities and promotion of local products. Development of ecological tourism and the satisfaction of the people involved in it depends on whether the tourism integration in the region's economy is active and proper. The basis for such integration should be the convergence of interests of the state, local self-governing bodies, tourism sector (private), environmental and social fields, but the creation of the modern tourist industry in the region (as well as throughout the country) and attraction of local or foreign tourists is accompanied by problems in view point of ecology and organization.

Study of this issue is first of all necessary for human health and then for Georgia as a country with a growing tourist potential. In this regard, it is important to maintain the high quality of atmospheric air because those not positive results published by international research organizations can negatively impact the country's tourist image. Intense atmospheric, water and soil pollution and excessive industry and transport noise is incompatible with leisure and comfort. Pollutant substances produced by agricultural activity reduces attractiveness of the landscape. In case of high pollution, it is generally unacceptable to use the landscape for recreational purposes.

During tourism and recreational studies it is necessary to study the sanitary and hygienic and ecological conditions that affect health and leisure of recreation tourists. It is important to study the impact of anthropogenic effects on the

\section{Distribution of Average Monthly Number of Visits by Visitors in 2017}

\begin{tabular}{|l|c|c|c|c|c|c|c|c|}
\hline & \multicolumn{4}{|c|}{ Annual, 2016} & \multicolumn{3}{c|}{ Annual, 2017 } \\
\hline Region & Visitor number & $\%$ & $\begin{array}{c}\text { Number of } \\
\text { visits }\end{array}$ & $\%$ & $\begin{array}{c}\text { Visitor } \\
\text { number }\end{array}$ & $\%$ & Number of visits & $\%$ \\
\hline Tbilisi & 204,2 & 23,3 & 264,0 & 24,3 & 213,1 & 24,6 & 269,0 & 25,4 \\
\hline Abkhazia A/R & 1,2 & 0,1 & 1,4 & 0,1 & 1,5 & 0,2 & 1,7 & 0,2 \\
\hline Ajara A/R & 100,5 & 11,5 & 117,5 & 10,8 & 111,0 & 12,8 & 136,1 & 12,9 \\
\hline Guria & 25,7 & 2,9 & 30,9 & 2,8 & 26,0 & 3,0 & 30,4 & 2,9 \\
\hline Imereti & 175,8 & 20,1 & 223,0 & 20,5 & 163,2 & 18,8 & 196,0 & 18,5 \\
\hline Kakheti & 72,0 & 8,2 & 84,1 & 7,7 & 63,0 & 7,3 & 73,3 & 6,9 \\
\hline Mtskheta-Mtianeti & 55,2 & 6,3 & 66,0 & 6,1 & 53,7 & 6,2 & 64,9 & 6,1 \\
\hline $\begin{array}{l}\text { Racha-Lechkhumi } \\
\text { and Kvemo Svaneti }\end{array}$ & 12,4 & 1,4 & 15,5 & 1,4 & 14,5 & 1,7 & 16,9 & 1,6 \\
\hline $\begin{array}{l}\text { Samegrelo-Zemo } \\
\text { Svaneti }\end{array}$ & 69,2 & 7,9 & 81,5 & 7,5 & 66,7 & 7,7 & 77,4 \\
\hline Samtskhe-Javakheti & 35,8 & 4,1 & 42,9 & 4,0 & 41,0 & 4,7 & 48,0 & 7,3 \\
\hline Kvemo Kartli & 61,1 & 7,0 & 75,5 & 7,0 & 55,0 & 6,3 & 68,8 \\
\hline Shida Kartli & 63,7 & 7,3 & 83,4 & 7,7 & 58,8 & 6,8 & 75,3 & 6,5 \\
\hline Total & 877,0 & 100,0 & 1085,9 & 100,0 & 867,5 & 100,0 & 1057,9 & 100,0 \\
\hline
\end{tabular}


environment, which manifests itself in organizing recreational utilization of nature.

The state policy of tourism development in Georgia should be founded on the concept of national security and economic development in order to increase the share of tourism in the country's economy by taking into consideration all areas of interest. It is recommended that the Government take into account its economic, ecological, social and organi- zational aspects in determining the strategic direction of economic security of tourism.

Solving these problems is broadly related to social justice and struggle for democracy and does not depend only on how well the experts understand the existing problems. Solution of those is primarily related to the fact that there is a political will that a real solution to ecological issues is on the agenda.

\section{REFERENCES:}

1. Birjakov M. B. (2014). Economic security of tourism. Tbilisi.

2. Shubladze V. (2004). Macroeconomic regulation mechanism of tourism development in Georgia (in the context of poverty reduction).

3. Maglakelidze T. (2002). Economic security. "News" Tbilisi.

4. Rajebashvili G. (2012). Tourism development in Georgia, essay of public policy.

5. Natroshvili G. (2012). National security objectives, facts and indicators. New Opinion, No.8. (14).

6. Study of Social and Economic Conditions and Attitudes of Kvemo Kartli Population, Institute of Social Research and Analysis (2012). Tbilisi.

7. Kvemo Kartli Development Strategy for 2014-2021

8. A.G. Belonogov (2010). Formation of a system for ensuring the economic security of the tourism sector. St. Petersburg.

9. Kosolopov, A. G. (2009). Problems of security of the tourist business and minimization of the main risk factors, Rev. "Knorus": Moscow.

10. http://geostat.ge

11. http://www.cida.ge/site/index.php/Geo

12. http://static.mrdi.gov.ge

13. https://www.radiotavisupleba.ge

14. https://sao.ge

15. http://netgazeti.ge/news

16. http://www.moe.gov.ge

17. http://liberali.ge 


\section{THE IMPACT OF ECOLOGICAL FACTORS ON TOURISM DEVELOPMENT IN KVEMO KARTLI REGION}

NINO LETANDZE

https://doi.org/10.35945/gb.2018.06.037

Assistant Professor

Georgian National University, Georgia

nletandze@mail.ru

\section{KEY WORDS: ECOLOGICAL SAFETY, ECOLOGICAL SAFETY OF TOURISM, TOURISM POTENTIAL,}

RATIONAL NATURE UTILIZATION, ENVIRONMENT

\section{SUMMARY}

In this Article we discuss environmental issues necessary for safe and sustainable development of tourism as an integral part of economic relations. We focus to examine the impact of anthropogenic effects on the environment, which manifests itself in organizing recreational utilization of nature.
We refer here to the impact of ecological problems on human health in Kvemo Kartli region, which is very attractive tourist destination and has a great potential for tourism development as of its cultural and historic heritage. 